\title{
STUDY ON THE SKIN TEST OF WHOOPING COUGH (III)
}

\author{
S. SOMEYA, Y. KANEKO AND K. UEHARA \\ Department of Public Health Microbiology, Institute of Public \\ Health, Tokyo
}

(Received: February 5th, 1955)

\section{INTRODUCTION}

In our country, there have been many reports on the skin test of whooping cough by agglutinogen ${ }^{1}$ and its reliability was discussed by Matsumura ${ }^{3}$ and the present authors, 4. In this report, the reliability of this skin test and the relationship between the skin reaction and the susceptibility to whooping cough are examined from the results of the 3 years field study.

The agglutinogen was, as described by Smolens and Mudd $\mathbf{1}$, prepared from phase I or II $H$. pertussis ${ }^{5,6}$ grown on Bordet and Gengou medium. The antigen was filtered through Seitz-filter and tested for potency by both in vitro and in vivo methods, and then applied to children. The erythema and the induration were read at the end of 24 hours or 48 hours.

\section{EXPERIMENTAL RESULTS}

\section{The skin reaction of infants}

Shown in Table 1 are the results of the skin test carried on the infants in a rural district which had only few cases of whooping cough for the last few years. The age of the children and infants used in this experiment were from 3 to 26 months and they had no previous history of whooping cough according to the information by their families. As shown in Table 1, the older the children, there were the more positive reactors. In this case the reactions ranged over

Table 1. The skin test on the infant and children (3-26 months old)

\begin{tabular}{|c|c|c|c|c|c|c|c|c|c|c|c|c|c|}
\hline \multirow{2}{*}{ Reaction } & \multirow{2}{*}{$\begin{array}{c}\text { Age } \\
\text { by } \\
\text { month }\end{array}$} & \multicolumn{11}{|c|}{ Diameter in $\mathrm{mm}$} & \multirow{2}{*}{ Total } \\
\hline & & $\begin{array}{l}0 \\
1\end{array}$ & $\begin{array}{l}2 \\
3\end{array}$ & $\begin{array}{l}4 \\
5\end{array}$ & $\begin{array}{l}6 \\
7\end{array}$ & $\begin{array}{l}8 \\
9\end{array}$ & $\begin{array}{l}10 \\
11\end{array}$ & $\begin{array}{l}12 \\
13\end{array}$ & $\begin{array}{l}14 \\
15\end{array}$ & $\begin{array}{l}16 \\
17\end{array}$ & $\begin{array}{l}18 \\
19\end{array}$ & $\begin{array}{c}20 \\
\text { over }\end{array}$ & \\
\hline \multirow{2}{*}{$\begin{array}{l}\text { Induration } \\
\text { after } \\
24 \text { hours }\end{array}$} & $\begin{array}{r}3-6 \\
7-12 \\
13-\end{array}$ & $\begin{array}{l}10 \\
20 \\
68\end{array}$ & 1 & $\begin{array}{l}2 \\
2\end{array}$ & $\begin{array}{l}3 \\
3 \\
4\end{array}$ & $\begin{array}{l}3 \\
4\end{array}$ & $\begin{array}{r}1 \\
8 \\
13\end{array}$ & $\begin{array}{r}1 \\
14\end{array}$ & $\begin{array}{l}2 \\
3\end{array}$ & $\begin{array}{l}1 \\
1\end{array}$ & 3 & 1 & $\begin{array}{r}14 \\
40 \\
114\end{array}$ \\
\hline & Total & 98 & 1 & 4 & 10 & 7 & 22 & 15 & 5 & 2 & 3 & 1 & 168 \\
\hline \multirow{2}{*}{$\begin{array}{l}\text { Erythema } \\
\text { after } \\
48 \text { hours }\end{array}$} & $\begin{array}{r}3-6 \\
7-12 \\
13-\end{array}$ & $\begin{array}{l}3 \\
2 \\
9\end{array}$ & $\begin{array}{r}2 \\
6 \\
27\end{array}$ & $\begin{array}{r}5 \\
14 \\
25\end{array}$ & $\begin{array}{r}2 \\
5 \\
19\end{array}$ & $\begin{array}{r}1 \\
8 \\
15\end{array}$ & $\begin{array}{l}1 \\
5 \\
5\end{array}$ & 3 & 2 & 2 & & & $\begin{array}{r}14 \\
40 \\
107\end{array}$ \\
\hline & Total & 14 & 35 & 44 & 26 & 24 & 11 & 3 & 2 & 2 & & & 161 \\
\hline
\end{tabular}


$10 \mathrm{~mm}$ was taken as positive. Felton reported that an induration $10-20 \mathrm{~mm}$ in diameter should be regarded as a weakly positive immune reaction. There are some workers, on the other hand, who think mere presence of an induration as positive reaction.

In our previous report ${ }^{2}$ of the studies on the skin test of pertussis, it was described that, in the case of 10 units of agglutinogen, an induration ranged over $10 \mathrm{~mm}$ in diameter after 24 hours and an erythem ranged over $10 \mathrm{~mm}$ after 48 hours were considered as positive reaction. But the final decision was reserved for farther investigation.

As shown in Table 2, these children were tested 6 weeks after completion of the inoculation of pertussis vaccine. The Lot of the agglutinogen used in Table 1 and 2 was the same. The percentage of post-vaccinal positive reactors was extremely low compared with the results reported by Felton, Sauer and others. The immunizing potency of Japanese pertussis vaccine may be inferior to that of the U.S.A.

Table 2. The skin test before and 6 weeks after the vaccination (Induration after 24 hours)

\begin{tabular}{|c|c|c|c|c|c|c|c|c|c|c|c|c|c|c|c|c|c|c|c|}
\hline & \multicolumn{17}{|c|}{ after the vaccination } & \\
\hline & & $\begin{array}{l}0 \\
1\end{array}$ & $\begin{array}{l}2 \\
3\end{array}$ & $\begin{array}{l}4 \\
5\end{array}$ & $\begin{array}{l}6 \\
7\end{array}$ & $\begin{array}{l}8 \\
9\end{array}$ & $\begin{array}{l}10 \\
11\end{array}$ & $\begin{array}{l}12 \\
13\end{array}$ & $\begin{array}{l}14 \\
15\end{array}$ & $\begin{array}{l}16 \\
17\end{array}$ & $\begin{array}{l}18 \\
19\end{array}$ & $\begin{array}{l}20 \\
21\end{array}$ & $\begin{array}{l}22 \\
23\end{array}$ & $\begin{array}{l}24 \\
25\end{array}$ & $\begin{array}{l}26 \\
27\end{array}$ & $\begin{array}{l}28 \\
29\end{array}$ & $\begin{array}{l}30 \\
31\end{array}$ & $\begin{array}{l}32 \\
33\end{array}$ & \\
\hline 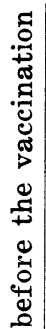 & $\begin{array}{r}0-1 \\
2-3 \\
4-5 \\
6-7 \\
8-9 \\
10-11 \\
12-13 \\
14-15 \\
16-17 \\
18-19 \\
20-21\end{array}$ & $\begin{array}{r}21 \\
2 \\
1 \\
\\
5 \\
5\end{array}$ & & 1 & 1 & 4 & $\begin{array}{l}2 \\
\\
2 \\
1 \\
2 \\
1\end{array}$ & $\begin{array}{l}8 \\
1 \\
1 \\
\\
1 \\
2 \\
2 \\
1\end{array}$ & $\begin{array}{l}9 \\
\\
2 \\
1 \\
2 \\
2 \\
1\end{array}$ & $\begin{array}{l}1 \\
3 \\
1\end{array}$ & 7 & 1 & 2 & 1 & & & & 1 & $\begin{array}{r}62 \\
1 \\
3 \\
7 \\
3 \\
17 \\
11 \\
3 \\
1 \\
1\end{array}$ \\
\hline & Total & 34 & & 1 & 1 & 4 & 8 & 16 & 17 & 13 & 9 & 1 & 3 & 1 & & & & 1 & 109 \\
\hline
\end{tabular}

\section{Skin reaction of school children}

The same agglutinogen used in Table 1 was applied on the primary school children (aged from 6 to 12 years) in a rural district in which there had been an epidemic of whooping cough. The test was carried out immediately after completion of the epidemic. These children had no experience of pertussis vaccination. As shown in Table 3, the percentage of positive reactors was extremely higher than in Table 1 and it is interesting to note that the percentage of the positive reactors among older children after epidemic was slightly lower than that of younger children. This contradictory phenomenon is considered probably due to the fact that the cases from the older age group were fewer than the younger, because the percentage of already infected children among the older was higher than that of the younger before the epidemic and those children already infected played the part of a filter in protecting pertussis infection. 
Table 3. The skin test on the primary school children

(Induration after 24 hours)

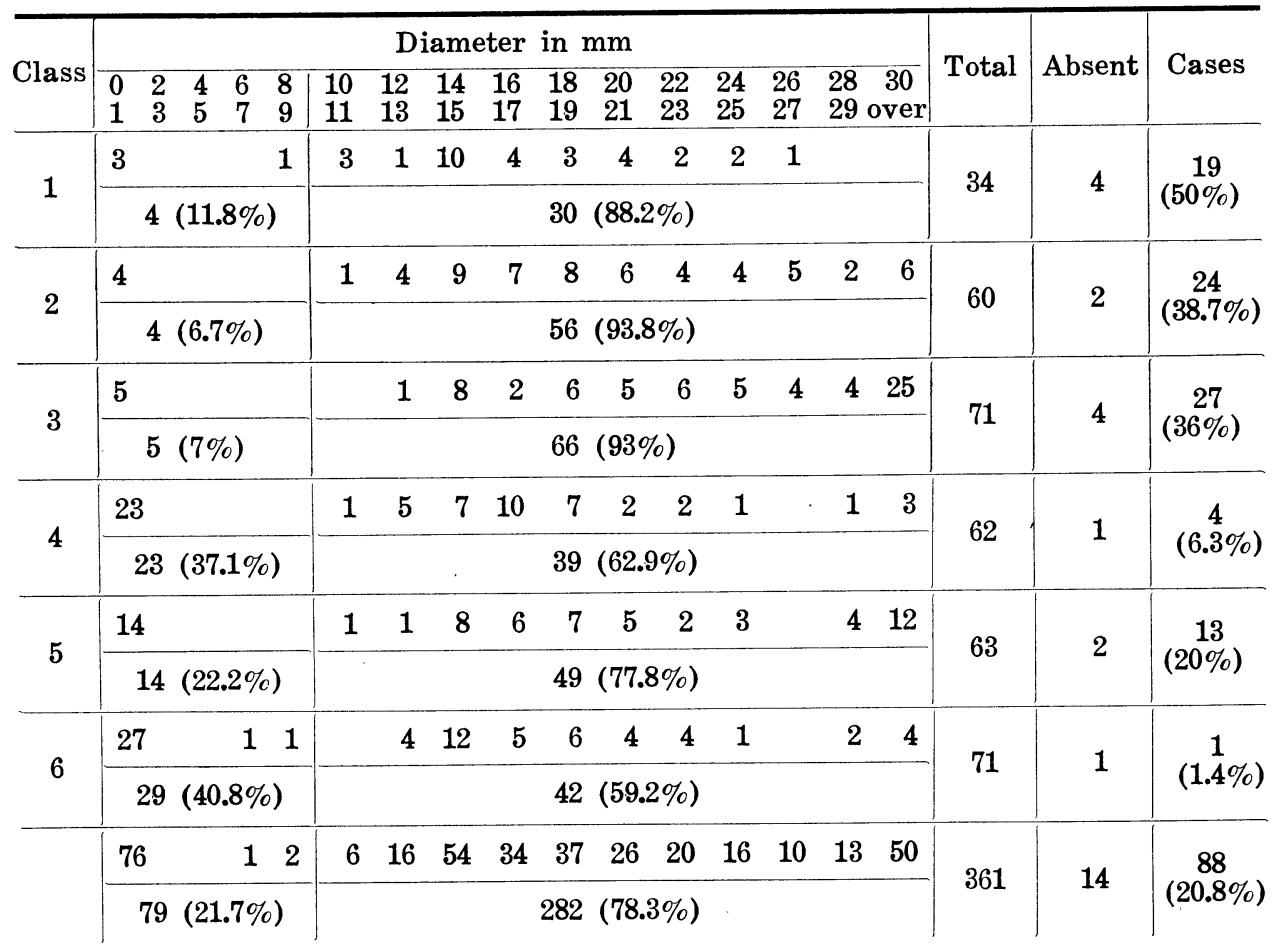

Table 4. The relationship between the skin reaction* and the apparent infection in the case of the school children

a) In the case of the children having no history and not infected apparently

\begin{tabular}{|c|c|c|c|c|c|}
\hline & \multicolumn{4}{|c|}{ Diameter in $\mathrm{mm}$} & \multirow{2}{*}{ Total } \\
\hline & $0-4$ & $5-9$ & $10-19$ & $20-$ & \\
\hline \multirow{2}{*}{$\begin{array}{c}\text { No. of tested } \\
\%\end{array}$} & $4^{* *}$ & & 19 & 8 & \multirow{2}{*}{31} \\
\hline & \multicolumn{2}{|c|}{$13 \%$} & \multicolumn{2}{|c|}{$87 \%$} & \\
\hline
\end{tabular}

Notes: * Induration after 24 hours

* Erythema after 24 hours; 13, 15, 17 and $17 \mathrm{~mm}$

b) In the case of the children who were infected apparently in this epidemic

\begin{tabular}{|c|c|c|c|c|c|}
\hline & \multicolumn{4}{|c|}{ Diameter in $\mathrm{mm}$} & \multirow{2}{*}{ Total } \\
\hline & $0-4$ & $5-9$ & $10-19$ & $20-$ & \\
\hline \multirow{2}{*}{$\begin{array}{c}\text { No. of tested } \\
\%\end{array}$} & $6 *$ & & 18 & 19 & \multirow{2}{*}{43} \\
\hline & \multicolumn{2}{|c|}{$14 \%$} & \multicolumn{2}{|c|}{$86 \%$} & \\
\hline
\end{tabular}

Note: Erythema after 24 hours; 10, 10, 13, 15, 18 and $21 \mathrm{~mm}$ 
And the relationship between the skin reaction and the apparent infection was examined on the children who had been home-exposed during this epidemic. As shown in Table $4 \mathrm{a}, 87 \%$ of the children having no so-called history of whooping cough and not infected apparently in this epidemic were positive reactors. This means that they had been already infected inapparently. On the other hand, $86 \%(37 / 43)$ of the children, who had been attacked apparently in this epidemic were positive reactors. The remaining 6 cases, negative reactors judged from the induration after 24 hours, are considered due to the fact that the interval from the beginning of the disease to the skin test was too short to react positively. According to our unpublished data, the patients react positively 3 weeks after onset of the disease. Accordingly, almost all the infected children are considered to become positive reactors.

Furthermore, in the case of Table $4 \mathrm{~b}$, it should be taken into consideration that the induration is very difficult to measure accurately. From this point of view, the problem as to whether erythema can be taken as the criterion for the skin reaction or not is a problem for future investigation in spite of the fact that there have been no report based on erythema.

Table 5. The results of the follow-up study for 3 years of the skin test

\begin{tabular}{|c|c|c|c|c|c|c|}
\hline Group & family & object & $\begin{array}{l}\text { skin reaction } \\
\text { at Oct. } 1951\end{array}$ & $\begin{array}{l}\text { number of the } \\
\text { vaccination }\end{array}$ & $\begin{array}{c}\text { skin reaction at } \\
\text { April } 1951\end{array}$ & attacked \\
\hline I & A & $\begin{array}{l}1 \\
2\end{array}$ & $\begin{array}{l} \pm \\
+\end{array}$ & 4 & + & $\begin{array}{l}t \\
-\end{array}$ \\
\hline II & B & $\begin{array}{l}3 \\
4\end{array}$ & $\overline{-}$ & $\begin{array}{l}4 \\
4\end{array}$ & $\bar{t}$ & $\begin{array}{l}+ \\
+\end{array}$ \\
\hline III & C & $\begin{array}{c}(5) \\
6 \\
7 \\
\end{array}$ & $\begin{array}{l}- \\
\pm\end{array}$ & $\begin{array}{l}5 \\
4 \\
\end{array}$ & $\begin{array}{l}+ \\
\pm\end{array}$ & $\begin{array}{l}+ \\
+ \\
+\end{array}$ \\
\hline \multirow{7}{*}{ IV } & D & $\begin{array}{c}8 \\
(9) \\
\end{array}$ & - & 5 & \pm & $\begin{array}{l}+ \\
+\end{array}$ \\
\hline & $\mathbf{E}$ & $\begin{array}{c}(10) \\
11\end{array}$ & - & 5 & + & $\begin{array}{l}+ \\
+\end{array}$ \\
\hline & F & $\begin{array}{l}12 \\
13 \\
\end{array}$ & - & $\begin{array}{l}5 \\
5 \\
\end{array}$ & $\begin{array}{l} \pm \\
+\end{array}$ & $\begin{array}{l}+ \\
+\end{array}$ \\
\hline & G & $\begin{array}{l}14 \\
15 \\
\end{array}$ & $\begin{array}{l}+ \\
+\end{array}$ & & & - \\
\hline & $\mathbf{H}$ & 16 & \pm & 4 & \pm & - \\
\hline & I & 17 & - & 5 & $H$ & - \\
\hline & $\mathbf{J}$ & $\begin{array}{c}(18) \\
19 \\
20 \\
21\end{array}$ & $\begin{array}{l}- \\
- \\
-\end{array}$ & $\begin{array}{l}5 \\
5 \\
4 \\
5\end{array}$ & $\begin{array}{l}+ \\
\pm\end{array}$ & $\begin{array}{l}+ \\
- \\
+\end{array}$ \\
\hline
\end{tabular}


3. The relationship between the skin reaction and the natural infection

Table 5 shows the results of the follow-up study of the skin test previously reported ${ }^{2}$. The children were attentively observed during Oct. 1950-Sept. 1953. The children listed in Table 5 are either the pertussis patients or the children presumably exposed to them in the home or in the neighborhood. As shown in Table 5, all of the patients had been negative or doubtfully positive (5-9 $\mathrm{mm}$.) reactors. Although they were inoculated with pertussis vaccine and some of them became positive reactors, they were apparently infected at the end of $\mathbf{1 9 5 0 .}$ It seems very difficult to discuss the relationship between the immunity and the skin reaction in the case of the children inoculated with pertussis vaccine, because the interval from the skin test to the infection was about 6 months and during which period there might be the decrease of immunity and the negative conversion of the skin reaction.

It is to be noted in Table 5 that 3 positive reactors who received no vaccination had experienced no attack of whooping cough. Conclusively, the susceptibility of negative reactors and the immunity of positive reactors are considered to be confirmed in the natural epidemic. This observation is still undergoing, but will be complemented in near future.

\section{Discussion}

It goes without saying that the reliability of the skin reaction should be examined on the children having the history and not having the history of the disease. But in the field, it is almost impossible to know accurate history.

The examination results shown in Table 1 may be the best of the skin reaction in the field on the young infant who were considered to be susceptible to whooping cough. On the other hand, it is considered almost impossible to examine the reliability of the skin reaction on the children having so-called history, because not all the children are diagnosed by the physician and based on the bacteriological examination. Regarding to this point, refer to reference (8).

Thus it is very difficult to correlate the history and the skin reaction, and the discrepancy to some extent between them seems unavoidable in the case of the field study. Such an observation as shown in Table 5 will be most important to examine the reliability of the Skin Reaction.

\section{CONCLUSIONS}

1. A total of 600 children, who were tested previously by the skin reaction, had been observed for 3 years, and 17 cases outbreaked from them. These 17 cases were all negative reactors and the positive reactors exposed to them escaped the infection.

2. Two groups, the young infant and the children of school age, were tested by the same Lot of agglutinogen. And it was confirmed that the percentage of positive reactors of each group was noticeably different and there were more inapparent infections in the children of school age than the young infant. 
3. A total of 109 infants were tested of their skin reaction before and after vaccination and the percentage of positive reactors was lower than that of Felton et al. From this point, it is supposed that the immunizing potency of pertussis vaccine in Japan might be inferior to that of the U.S.A.

The authors wish to express their heartfelt thanks for the generous Grand in Aid subsidized by the Ministry of Education.

\section{REFERENCES}

1) J. Smolens and S. Mudd: J. Imm., 47, 2, 155, 1943.

2) S. Someya, Y. Kaneko and A. Yamamoto: Bull. Inst. Pub. Health., June, 13, 1952.

3) T. Matsumura: The society of the Association for children., May, 1954.

4) S. Someya and Y. Kaneko: The society of the Japanese Association for Infections Diseases., April, 1953.

5) T. Kasuga et al: Japanese Journal of Bacteriology., 8, 841, 1953.

6) Y. Kaneko: Japanese Journal of Bacteriology., 8, 753, 1953.

7) M. Felton, et al: J. Ped., 29, 6, 677, 1946.

8) Y. Kaneko: The Journal of Public Health., 13, 9, 1953.

9) K. Uehara: "Rinsho"., 6, 7, 1953. 